\title{
Effect of Bentonite Fining on Proteins and Phenolic Composition of Chardonnay and Sauvignon Blanc Wines
}

\author{
Shan $\mathrm{He}^{1,2}$, Richard Hider ${ }^{3}$, Jenny Zhao ${ }^{3}$, Bin $\operatorname{Tian}^{3 *}$ \\ (1) Department of Food Science and Engineering, Guangzhou University, Guangzhou 510006, PR China \\ (2) Institute for NanoScale Science and Technology, College of Science and Engineering, Flinders University, Bedford Park \\ 5042, Australia \\ (3) Faculty of Agriculture and Life Sciences, Lincoln University, Lincoln 7647, New Zealand
}

Submitted for publication: December 2019

Accepted for publication: March 2020

Key words: Bentonite, Chardonnay, phenolic composition, protein, Sauvignon Blanc

\begin{abstract}
Bentonite fining is widely used to remove excess proteins in white wine prior to bottling in order to prevent protein haze formation. However, bentonite fining could also remove beneficial compounds in wine, e.g. phenolic compounds that contribute to sensory properties of wine. In this study, impact of bentonite fining on the phenolic composition of Chardonnay and Sauvignon Blanc wines has been investigated using four different bentonites: pluxcompact (PCT, Ca bentonite); bentolit (BTL, Na-Ca bentonite); pluxbenton (PBN, Na bentonite); and sperimentale (SPM, Ca-Na bentonite). Different bentonites showed similar efficiencies in removing haze-related proteins and resulted in significant decrease in total phenolic concentration. Impact on phenolic composition varied depending on the type of bentonite. In this study, fining with Ca-Na bentonite (SPM) resulted in the lowest concentrations of caftaric acid and flavanols, particularly epicatechin gallate, gallocatechin, catechin and epicatechin, which could lead to reduced mouthfeel of the resultant wine. Results presented in this study provided additional information for winemakers to choose appropriate bentonite to remove proteins with a minimal effect on reduction of phenolic compounds.
\end{abstract}

\section{INTRODUCTION}

Bentonites are hydrated aluminium silicates which consist mostly of montmorillonite (Ribéreau-Gayon, Peynaud, Ribéreau-Gayon, \& Sudraud, 1977). There are many different types of bentonite, such as potassium bentonite (K bentonite), sodium bentonite ( $\mathrm{Na}$ bentonite), calcium bentonite ( $\mathrm{Ca}$ bentonite) and aluminium bentonite ( $\mathrm{Al}$ bentonite). For commercial use, sodium bentonite and calcium bentonite are the two main classes. Calcium bentonite can be converted to sodium-activated bentonite ( $\mathrm{Ca}-\mathrm{Na}$ or $\mathrm{Na}-\mathrm{Ca}$ bentonite) by exposure to sodium carbonate at $80^{\circ} \mathrm{C}$ which results in an exchange of sodium for calcium (Gougeon et al., 2003).

In wine industry, fining with bentonite is widely used to remove proteins in white wine before bottling as excess proteins, predominantly two groups of pathogenesis-related (PR) proteins: thaumatin-like proteins (TLPs) and chitinases, could cause protein haze formation that makes wine appear cloudy and unacceptable by consumers (Ferreira, PicarraPereira, Monteiro, Loureiro, \& Teixeira, 2002; Muhlack, O’Neill, Waters, \& Colby, 2016; Waters et al., 2005). However, bentonite fining also has disadvantages. Firstly, bentonite fining could lead to the loss of wine volume due to lees formation. Depending on the type of bentonite, the lees formed after fining are varied, i.e. sodium bentonite has a high capacity of water absorption and it can swell up to 15 times its volume, while calcium bentonite has a lower swelling capacity but higher in lees compaction, compared to sodium bentonite. A study which estimated the value of wine loss due to bentonite addition every year globally, was about 1 billion dollars (Majewski, Barbalet, \& Waters, 2011). Secondly, bentonite is not specific to absorb proteins; as a result, bentonite fining could remove aroma compounds (Lambri, Dordoni, Silva, \& De Faveri, 2010; Vincenzi, Panighel, Gazzola, Flamini, \& Curioni, 2015). It may also remove phenolic compounds (Ghanem et al., 2017; Jiménez-Martínez, Bautista-Ortín, Gil-Muñoz, \& GómezPlaza, 2019), which are associated with antioxidant activities (Dumitriu, de Lerma Extremera, Cotea, \& Peinado, 2018) and the colour of red wine (Dordoni, Galasi, Colangelo, De Faveri, \& Lambri, 2015). Previous studies have focused on the impact of bentonite fining on phenolic compounds in red wine, as extraction of phenolic compounds is critical for red wine quality (Dordoni, Galasi, et al., 2015; Gómez-Plaza, GilMuñoz, López-Roca, De La Hera-Orts, \& Martínez-Cultíllas, 2000; Stanković, Jović, \& Živković, 2004). Limited studies have been conducted to investigate the impact of bentonite fining on white wine phenolics (Dordoni, Colangelo, et al.,

*Corresponding author: E-mail address: bin.tian@lincoln.ac.nz

Acknowledgements: Authors would like to express their great appreciation to Shirley Joseph from Enartis Pacific for kindly providing all bentonite samples used in this study. Wine samples provided by Waipara Hills are also gratefully acknowledged 
2015; Main \& Morris, 1994). However, a recent review has revealed the importance of phenolics in white wine to the mouthfeel (Gawel, Smith, Cicerale, \& Keast, 2017), and the interactions between phenolics, alcohol and acidity, which plays an important role in determining the mouthfeel and bitterness of white wine (Gawel, Schulkin, Day, Barker, \& Smith, 2016). Thus, changes in phenolic concentration and phenolic composition would affect the quality of white wine. This study was aimed to investigate the impact of fining on the phenolic compounds in Chardonnay and Sauvignon Blanc wines using four different types of bentonite.

\section{MATERIALS AND METHODS \\ Chemicals}

A range of phenolic standards at HPLC grade $(>90 \%$ purity) were purchased from Sigma-Aldrich, except noted individually: gallic acid, protocatechuic acid, gallocatechin, caftaric acid, hydrobenzoic acid, epigallocatechin, catechin, vanilic acid (97.0\%), caffeic acid, syringic acid, epicatechin, p-coumaric acid, rutin, epicatechin gallate, and quercetin. The solvents and chemicals used in HPLC analysis include acetonitrile and methanol (HPLC grade, Lichrosolv), ammonium dihydrogen phosphate (99\% purity, AnalaR), and orthophosphoric acid (analytical grade, Ajax Finechem).

\section{Wine samples}

Chardonnay and Sauvignon Blanc wines were donated by Waipara Hills Wines, New Zealand. Both wines were barrel fermented in 2018 using indigenous yeasts. Sauvignon Blanc was fermented with grape skin. Samples of both Sauvignon Blanc and Chardonnay were collected before bottling without any fining or filtration. Alcohol content, $\mathrm{pH}$, residual sugar, and titratable acidity (TA) were determined on the wines (Iland, Bruer, Edwards, Weeks, \& Wilkes, 2013).

\section{Bentonite treatments}

Four types of bentonites used in this study were provided by Enartis Pacific Napier, New Zealand: pluxcompact (PCT, $\mathrm{Ca}$ bentonite), bentolit (BTL, Na-Ca bentonite), pluxbenton (PBN, Na bentonite), and sperimentale (SPM, Ca-Na bentonite). To determine bentonite addition rate for protein stabilization in wines, the heat test was carried out at $80^{\circ} \mathrm{C}$ for $6 \mathrm{~h}$. Bentonite requirements were determined at $50 \mathrm{mg} / \mathrm{L}$ for Chardonnay and at $30 \mathrm{mg} / \mathrm{L}$ for Sauvignon Blanc, respectively ( (Tian et al., 2017). Bentonite treated wines were stationary incubated overnight at $4{ }^{\circ} \mathrm{C}$, and centrifuged at $4000 \mathrm{~g}$ for $30 \mathrm{~min}$. Chardonnay and Sauvignon Blanc wines without addition of bentonite were used as controls.

\section{Analysis of PR proteins by HPLC}

The concentration of PR proteins in wines were determined using a reversed-phase HPLC method (Marangon, Van Sluyter, Haynes, \& Waters, 2009). Samples (50 $\mu \mathrm{L})$ were loaded at $1 \mathrm{~mL} / \mathrm{min}$ flow rate onto a C8 column $(4.6 \mathrm{x}$ $250 \mathrm{~mm}$, Vydac 208TP54, Grace Davison Discovery Sciences, Baulkham, Australia), fitted with a C8 guard column kit (4.6 x 5 mm, Vydac 208GK54, Grace Davison Discovery Sciences, Baulkham, Australia). The system was equilibrated in a mixture of $83 \%(\mathrm{v} / \mathrm{v})$ solvent B $(0.1 \%$ trifluoroacetic acid (TFA) in $8 \%$ acetonitrile) and $17 \%$ solvent A (80\% acetonitrile, $0.1 \%$ (v/v) TFA). Column temperature was $35{ }^{\circ} \mathrm{C}$. In this study, the peaks eluting between 9 and 12 min were assigned as TLPs and the peaks eluting between 18 and 25 min were assigned as chitinases (Marangon et al., 2009; Salazar, López, Chiffelle, López, \& Peña-Neira, 2012; Van Sluyter et al., 2009). Quantification of TLPs and chitinases was conducted by comparison with the peak area of thaumatin from Thaumatococcus daniellii (Sigma-Aldrich, Auckland, New Zealand). The protein concentration was expressed as thaumatin equivalent (mg thaumatin/L).

\section{Determination of total phenolics}

The concentrations of total phenolics in wine samples were determined using a micro scale protocol for the FolinCiocalteau colorimetric reaction method (Waterhouse, 2002). Total phenolics were quantified against a gallic acid standard curve $(0$ to $500 \mathrm{mg} / \mathrm{L})$. The absorbance readings were taken

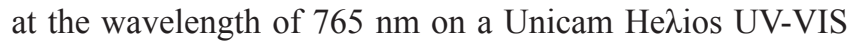
Spectrophotometer (Cambridge, UK). Total phenolics were expressed as gallic acid equivalents (mg GAE/L).

\section{Phenolic composition analysis by HPLC}

The analysis of phenolic composition was conducted using a method described by (Gómez-Alonso, García-Romero, \& Hermosín-Gutiérrez, 2007) with minor modifications. An Agilent HPLC equipped with quaternary pump and diodearray detector (DAD) and fluorescence detector (FLD) was used as identification and confirmation for some phenolic compounds. After injecting $10 \mu \mathrm{L}$ of wine sample, separation was conducted on an ACE $3 \mu$ C18 PFP $150 \times 4.6$ mm column (Advanced Chromatography Technologies, Aberdeen, Scotland) which was thermostat at $20^{\circ} \mathrm{C}$. The flow rate and solvent gradient used for separation are shown in Table 1. For detection of compounds, chromatograms were recorded at $280 \mathrm{~nm}, 320 \mathrm{~nm}, 360 \mathrm{~nm}$, and $520 \mathrm{~nm}$ in the DAD and corresponding to excitation at $280 \mathrm{~nm}$ and emission at $320 \mathrm{~nm}$ in the FLD. Identification of compounds were carried out by comparing their retention times and spectra with those of standards. Quantification of phenolic compounds was carried out by area measurements at $280 \mathrm{~nm}, 320 \mathrm{~nm}$ and FLD separately. Quantitative assays were achieved using external calibration curves for all standard phenolics by dissolution of the standard solution accordingly.

\section{Statistical analysis}

Data represent the means \pm standard deviation of three replicates. The concentrations of phenolic compounds in wine samples were analysed by analysis of variance (ANOVA). Least significant difference (LSD, 5\% level) was used to separate means when a significant $\mathrm{P}$-value was obtained.

\section{RESULTS AND DISCUSSION \\ Wine analysis \\ Physicochemical parameters}

Alcohol content, $\mathrm{pH}$, titratable acidity (TA) and reducing sugar were determined at $13.4 \%, 3.36,10.2 \mathrm{~g} / \mathrm{L}$ and $1.88 \mathrm{~g} / \mathrm{L}$ in Chardonnay, and at $13.6 \%, 3.65,8.5 \mathrm{~g} / \mathrm{L}$ and $2.05 \mathrm{~g} / \mathrm{L}$ in Sauvignon Blanc. (Table 2). Both wines were 
TABLE 1

Ternary mobile phase gradient of the HPLC method for phenolic analysis,

\begin{tabular}{ccccc}
\hline Time (min) & Flow rate (mL/min) & Solvent A (\%) & Solvent B (\%) & Solvent C (\%) \\
\hline 0.0 & 0.8 & 100.0 & 0.0 & 0.0 \\
2.0 & 0.8 & 100.0 & 0.0 & 0.0 \\
5.0 & 0.8 & 93.6 & 6.4 & 0.0 \\
17.0 & 0.8 & 2.8 & 11.2 & 86.0 \\
22.0 & 0.8 & 3.6 & 14.4 & 82.0 \\
29.5 & 0.8 & 4.2 & 16.8 & 79.0 \\
55.0 & 0.8 & 6.6 & 26.4 & 67.0 \\
70.0 & 0.8 & 10.0 & 40.0 & 50.0 \\
75.0 & 0.8 & 10.0 & 40.0 & 50.0 \\
78.0 & 0.8 & 36.0 & 64.0 & 0.0 \\
81.0 & 0.8 & 36.0 & 64.0 & 0.0 \\
86.0 & 0.8 & 100.0 & 0.0 & 0.0 \\
90.0 & 0.8 & 100.0 & 0.0 & 0.0 \\
\hline
\end{tabular}

Solvent A: $0.05 \mathrm{M} \mathrm{NH}_{4} \mathrm{H}_{2} \mathrm{PO}_{4}, \mathrm{pH}=2.6$; Solvent B: $100 \%$ acetonitrile; Solvent C: $0.2 \mathrm{M} \mathrm{H}_{3} \mathrm{PO}_{4}, \mathrm{pH}=1.5$

TABLE 2

Analysis of Chardonnay and Sauvignon Blanc wine physicochemical parameters,

\begin{tabular}{llc}
\hline Parameters & Chardonnay & Sauvignon Blanc \\
\hline Alcohol (\%) & $13.4 \pm 0.07$ & $13.6 \pm 0.14$ \\
$\mathrm{pH}$ & $3.36 \pm 0.01$ & $3.65 \pm 0.01$ \\
$\mathrm{TA}(\mathrm{g} / \mathrm{L})$ & $10.2 \pm 0.08$ & $8.5 \pm 0.12$ \\
Residual sugar $(\mathrm{g} / \mathrm{L})$ & $1.88 \pm 0.04$ & $2.05 \pm 0.07$ \\
\hline
\end{tabular}

fermented to dryness with residual sugar level lower than $4 \mathrm{~g} / \mathrm{L}$. Comparing to Chardonnay, Sauvignon Blanc had a higher $\mathrm{pH}$, which may partially explain its lower bentonite requirement for protein stabilization, as high wine $\mathrm{pH}$ could reduce the potential to form protein haze in response to heat (Mesquita et al., 2001).

\section{Protein removal by bentonite fining}

The concentrations of TLPs and chitinases in Chardonnay and Sauvignon Blanc wines were determined at $84.3 \mathrm{mg} / \mathrm{L}$ and $5.7 \mathrm{mg} / \mathrm{L}$, and at $49.4 \mathrm{mg} / \mathrm{L}$ and $3.0 \mathrm{mg} / \mathrm{L}$, respectively (Table 3), which are within the concentration range reported in previous studies (Le Bourse et al., 2011; Tian et al., 2017). Comparing to Sauvignon Blanc, Chardonnay had higher concentration of TLPs and chitinases, which could lead to a high bentonite requirement for protein stabilization as PR proteins have a linear correlation with bentonite requirement (Tian et al., 2017). After bentonite fining, the concentration of TLPs in Chardonnay was reduced to $5.3 \mathrm{mg} / \mathrm{L}, 4.9 \mathrm{mg} / \mathrm{L}$, $4.6 \mathrm{mg} / \mathrm{L}$ and $3.9 \mathrm{mg} / \mathrm{L}$ by adding $50 \mathrm{mg} / \mathrm{L}$ of PCT, BTL, PBN and SPM, respectively. Chitinases in Chardonnay were completely removed after bentonite fining. Both TLPs and chitinases in Sauvignon Blanc were completely removed after bentonite fining. Four types of bentonite samples (PCT, BTL, PBN and SPM) at the same addition rate have shown similar efficiency in removing PR proteins in both Chardonnay and Sauvignon Blanc wines, but the bentonite lees formation varied among the different types of bentonites with BTL (Na-Ca bentonite) resulting in the most fluffy lees and SPM (Ca-Na bentonite) the most compact lees (Fig. 1). To reduce the loss of wine volume due to bentonite lees formation, SPM is recommended for protein stabilization in comparison with the other three types of bentonite samples.

\section{Bentonite fining impacts on phenolic substances}

Phenolic compounds identified and quantified in this study are shown in Fig. 2. The concentration of total phenolics in Chardonnay was determined at $107.8 \mathrm{mg} / \mathrm{L}$, and it decreased to $94.8 \mathrm{mg} / \mathrm{L}, 98.9 \mathrm{mg} / \mathrm{L}, 95.3 \mathrm{mg} / \mathrm{L}$ and $95.3 \mathrm{mg} / \mathrm{L}$ after bentonite fining with PCT, BTL, PBN and SPM, respectively (Table 4). The concentrations of individual phenolic compounds determined in all wine samples are in the concentration ranges reported previously (Gawel et al., 2017; Goldberg, Karumanchiri, Soleas, \& Tsang, 
TABLE 3

Concentrations $(\mathrm{mg} / \mathrm{L})$ of TLPs and chitinases in Chardonnay $(\mathrm{CH})$ and Sauvignon Blanc $(\mathrm{SB})$ wines and wines treated with different types of bentonite,

\begin{tabular}{lcl}
\hline Treatment & \multicolumn{1}{c}{ TLPs ${ }^{*}$} & Chitinases * $\left.^{*} \mathbf{m g} / \mathbf{L}\right)^{*}$ \\
\hline $\mathrm{CH}$ (control) & $84.3 \pm 0.3$ & $5.7 \pm 0.2$ \\
$\mathrm{CH}+\mathrm{PCT}$ & $5.3 \pm 0.2$ & $\mathrm{ND}$ \\
$\mathrm{CH}+\mathrm{BTL}$ & $4.9 \pm 0.3$ & $\mathrm{ND}$ \\
$\mathrm{CH}+\mathrm{PBN}$ & $4.6 \pm 0.1$ & $\mathrm{ND}$ \\
$\mathrm{CH}+\mathrm{SPM}$ & $3.9 \pm 0.2$ & $\mathrm{ND}$ \\
$\mathrm{SB}($ control) & $49.4 \pm 0.2$ & $3.0 \pm 0.3$ \\
$\mathrm{SB}+\mathrm{PCT}$ & $\mathrm{ND}$ & $\mathrm{ND}$ \\
$\mathrm{SB}+\mathrm{BTL}$ & $\mathrm{ND}$ & $\mathrm{ND}$ \\
$\mathrm{SB}+\mathrm{PBN}$ & $\mathrm{ND}$ & $\mathrm{ND}$ \\
$\mathrm{SB}+\mathrm{SPM}$ & $\mathrm{ND}$ & $\mathrm{ND}$ \\
\hline
\end{tabular}

${ }^{*}$ Concentrations of TLP and chitinases determined by HPLC and expressed as thaumatin equivalent (mg thaumatin/L). ND: not detected.

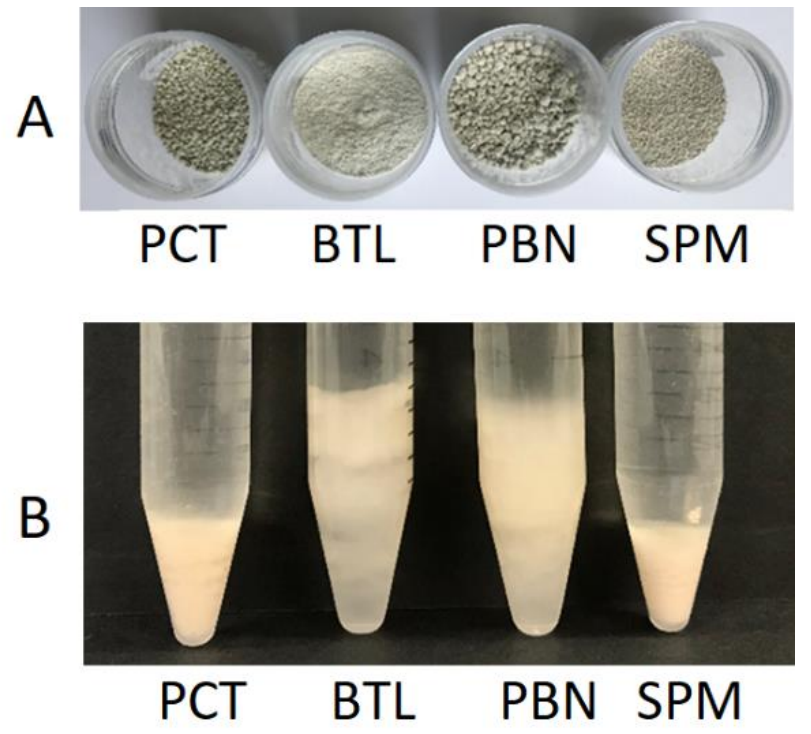

FIGURE 1

Particle sizes (A) of four bentonites used and lees formed (B) at addition rate of $50 \mathrm{mg} / \mathrm{L}$

1999). All phenolic compounds in Chardonnay (Table 4) were determined at lower concentrations compared to those in Sauvignon Blanc (Table 5). For Chardonnay wines, there were no significant differences for most of phenolic compounds observed among treatments, except for caffeic acid, $p$-coumaric acid and gallocatechin. The concentration of caffeic acid decreased significantly in Chardonnay after treatment with PCT, BTL and PBN, and the concentration of $p$-coumaric acid was significantly reduced in Chardonnay treated with PCT and BTL. All types of bentonite tested in this study showed significantly decreased the concentration of gallocatechin in Chardonnay, which may result in lower bitterness and astringency in wine. In addition, no caftaric acid was found in Chardonnay wines, indicating the occurrence of enzymatic oxidation during grape processing (Singleton, Salgues, Zaya, \& Trousdale, 1985).

The concentration of total phenolics in Sauvignon Blanc was determined at $414.8 \mathrm{mg} / \mathrm{L}$ (Table 5), which was higher than in Chardonnay, because Sauvignon Blanc was fermented with grape skin. After bentonite fining with PCT, BTL, PBN and SPM, the concentration of total phenolics decreased significantly to $409.4 \mathrm{mg} / \mathrm{L}, 340.4 \mathrm{mg} / \mathrm{L}$, $398.9 \mathrm{mg} / \mathrm{L}$ and $394.3 \mathrm{mg} / \mathrm{L}$, respectively. Reduction of total phenolics in white wine may reduce the perception of astringency, bitterness, hotness and viscosity (Gawel et al., 2016), but the effect is also dependent on $\mathrm{pH}$ and alcohol content of wine (Gawel, Van Sluyter, Smith, \& Waters, 2013). There were significant differences in the 


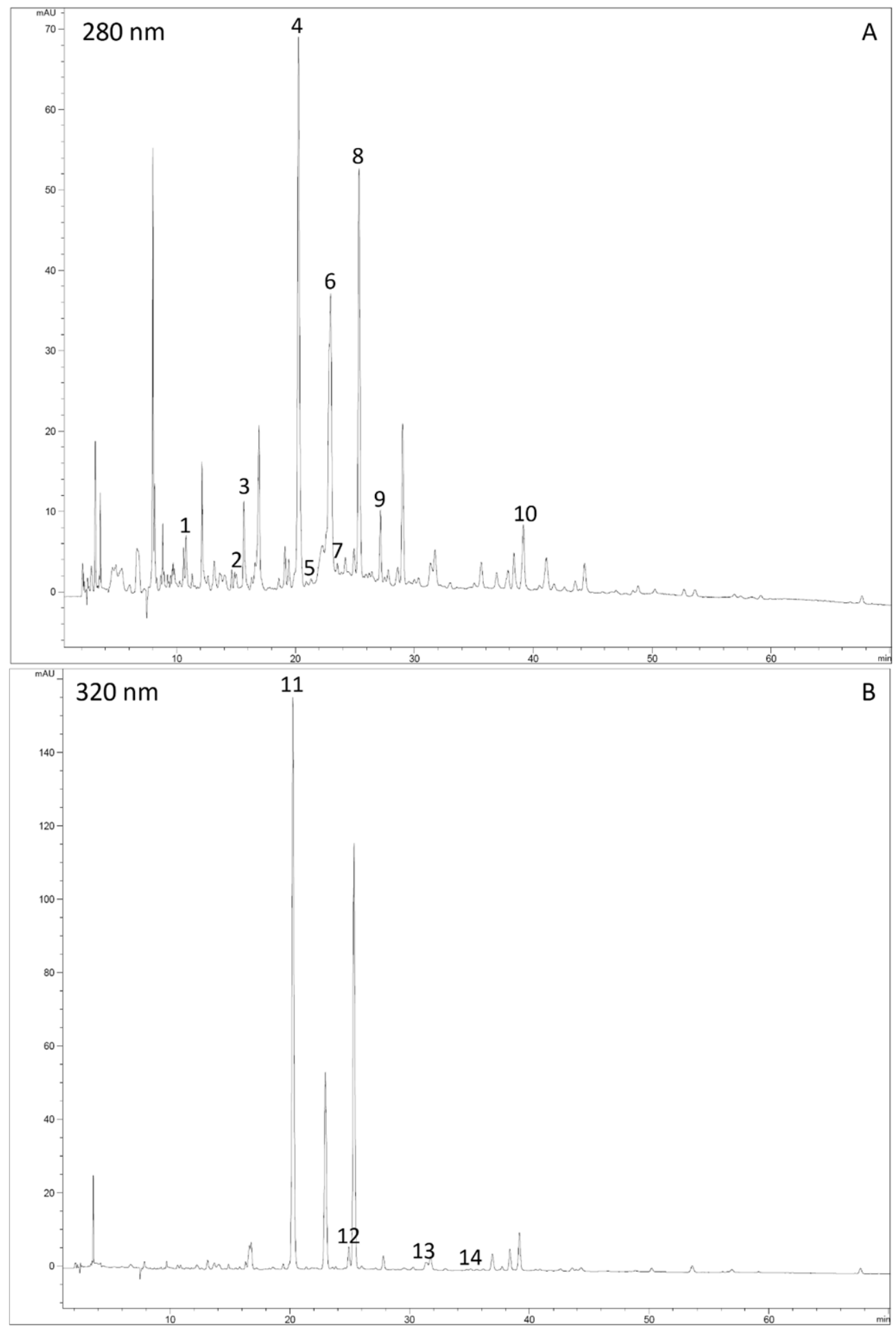

FIGURE 2

HPLC chromatograms of phenolics identified and quantified at $280 \mathrm{~nm}$ (A) and $320 \mathrm{~nm}(\mathrm{~B})$. 1: gallic acid; 2: protocatechuic acid; 3: gallocatechin; 4: hydrobenzoic acid; 5: epigallocatechin; 6: catechin; 7: vanilic acid; 8: syringic acid; 9: epicatechin; 10: epicatechin gallate; 11: caftaric acid; 12: caffeic acid; 13: p-coumaric acid; 14: ferulic acid.

concentrations of gallic acid, vanilic acid, caffeic acid, caftaric acid, epicatechin gallate, gallocatechin, catechin and epicatechin among treatments. Comparing within the four types of bentonites, SPM ( $\mathrm{Ca}-\mathrm{Na}$ bentonite) resulted in the lowest concentrations of caftaric acid and flavanols, particularly epicatechin gallate, gallocatechin, catechin and epicatechin. The significantly reduced caftaric acid found in SPM treated Sauvignon Blanc could negatively contribute to the mouthfeel of wine as caftaric acid could reduce burning and drying sensations without adding bitterness to white wine (Gawel, Schulkin, Smith, \& Waters, 2014). 
TABLE 4

Phenolic compounds $(\mathrm{mg} / \mathrm{L})$ in Chardonnay $(\mathrm{CH})$ wines and wines treated with different types of bentonite.

\begin{tabular}{|c|c|c|c|c|c|}
\hline \multirow[b]{2}{*}{ Phenolic compounds } & \multirow[b]{2}{*}{ Control } & \multicolumn{4}{|c|}{ Bentonite treatment } \\
\hline & & PCT & BTL & PBN & SPM \\
\hline \multicolumn{6}{|l|}{ Hydroxybenzoic acids } \\
\hline Gallic acid & $0.09^{a} \pm 0.01$ & $0.03^{b} \pm 0.01$ & $0.05^{\mathrm{ab}} \pm 0.01$ & $0.03^{b} \pm 0.01$ & $0.05^{\mathrm{ab}} \pm 0.01$ \\
\hline Protocatechuic acid & $0.41^{\mathrm{a}} \pm 0.06$ & $0.38^{\mathrm{a}} \pm 0.07$ & $0.30^{\mathrm{a}} \pm 0.01$ & $0.32^{\mathrm{a}} \pm 0.00$ & $0.28^{\mathrm{a}} \pm 0.02$ \\
\hline Vanilic acid & $0.38^{\mathrm{a}} \pm 0.01$ & $0.39^{\mathrm{a}} \pm 0.01$ & $0.36^{\mathrm{a}} \pm 0.01$ & $0.38^{\mathrm{a}} \pm 0.02$ & $0.38^{\mathrm{a}} \pm 0.01$ \\
\hline Syringic acid & $1.29^{\mathrm{a}} \pm 0.01$ & $1.23^{\mathrm{a}} \pm 0.04$ & $1.24^{\mathrm{a}} \pm 0.01$ & $1.24^{\mathrm{a}} \pm 0.01$ & $1.29^{\mathrm{a}} \pm 0.06$ \\
\hline Hydrobenzoic acid & $0.80^{\mathrm{a}} \pm 0.10$ & $0.75^{\mathrm{a}} \pm 0.08$ & $0.69^{a} \pm 0.02$ & $0.68^{\mathrm{a}} \pm 0.06$ & $0.68^{\mathrm{a}} \pm 0.06$ \\
\hline \multicolumn{6}{|l|}{ Hydroxycinnamic acids } \\
\hline Caffeic acid & $0.38^{\mathrm{a}} \pm 0.01$ & $0.30^{\mathrm{b}} \pm 0.01$ & $0.29^{\mathrm{b}} \pm 0.01$ & $0.30^{\mathrm{b}} \pm 0.01$ & $0.33^{\mathrm{ab}} \pm 0.02$ \\
\hline$p$-coumaric acid & $0.28^{\mathrm{a}} \pm 0.01$ & $0.20^{\mathrm{b}} \pm 0.04$ & $0.20^{\mathrm{b}} \pm 0.01$ & $0.21^{\mathrm{ab}} \pm 0.01$ & $0.22^{\mathrm{ab}} \pm 0.01$ \\
\hline Ferulic acid & $0.12^{\mathrm{a}} \pm 0.03$ & $0.12^{\mathrm{a}} \pm 0.02$ & $0.12^{\mathrm{a}} \pm 0.02$ & $0.11^{\mathrm{a}} \pm 0.00$ & $0.13^{\mathrm{a}} \pm 0.01$ \\
\hline Caftaric acid & ND & ND & ND & ND & ND \\
\hline \multicolumn{6}{|l|}{ Flavonols } \\
\hline Rutin & ND & ND & ND & ND & ND \\
\hline Quercetin & ND & ND & ND & ND & ND \\
\hline \multicolumn{6}{|l|}{ Flavanols } \\
\hline Epicatechin gallate & $0.37 \pm 0.19$ & ND & ND & ND & ND \\
\hline Gallocatechin & $16.28^{\mathrm{a}} \pm 0.86$ & $13.09^{b} \pm 1.22$ & $10.90^{b} \pm 0.00$ & $11.49^{b} \pm 0.47$ & $10.81^{\mathrm{b}} \pm 0.26$ \\
\hline Epigallocatechin & $2.47^{\mathrm{a}} \pm 0.47$ & $2.41^{\mathrm{a}} \pm 0.38$ & $2.12^{\mathrm{a}} \pm 0.09$ & $2.24^{\mathrm{a}} \pm 0.06$ & $2.03^{a} \pm 0.01$ \\
\hline Catechin & $0.63^{\mathrm{a}} \pm 0.05$ & $0.57^{\mathrm{a}} \pm 0.09$ & $0.56^{\mathrm{a}} \pm 0.10$ & $0.57^{\mathrm{a}} \pm 0.09$ & $0.57^{\mathrm{a}} \pm 0.09$ \\
\hline Epicatechin & ND & ND & ND & ND & ND \\
\hline Total phenolics* & $107.8^{\mathrm{a}} \pm 2.0$ & $94.8^{b} \pm 1.3$ & $98.9^{b} \pm 0.4$ & $95.3^{b} \pm 2.5$ & $95.3^{b} \pm 0.4$ \\
\hline
\end{tabular}

ND: not detected; different letters in the same row indicate a significant difference $(\mathrm{P}<0.05)$ according to one-way ANOVA and LSD test;

${ }^{*}$ Concentration of total phenolics is expressed as gallic acid equivalent (mg GAE/L).

TABLE 5

Phenolic compounds (mg/L) in Sauvignon Blanc (SB) wines and wines treated with different types of bentonite.

\begin{tabular}{|c|c|c|c|c|c|}
\hline \multirow[b]{2}{*}{ Phenolic compounds } & \multirow[b]{2}{*}{ Control } & \multicolumn{4}{|c|}{ Bentonite treatment } \\
\hline & & PCT & BTL & PBN & SPM \\
\hline \multicolumn{6}{|l|}{ Hydroxybenzoic acids } \\
\hline Gallic acid & $1.67^{\mathrm{a}} \pm 0.03$ & $1.46^{\mathrm{b}} \pm 0.00$ & $1.43^{b} \pm 0.04$ & $1.44^{b} \pm 0.06$ & $1.48^{\mathrm{b}} \pm 0.01$ \\
\hline Protocatechuic acid & $0.75^{\mathrm{a}} \pm 0.07$ & $0.71^{\mathrm{a}} \pm 0.06$ & $0.65^{\mathrm{a}} \pm 0.01$ & $0.66^{\mathrm{a}} \pm 0.01$ & $0.67^{\mathrm{a}} \pm 0.01$ \\
\hline Vanilic acid & $0.80^{\mathrm{a}} \pm 0.08$ & $0.52^{\mathrm{ab}} \pm 0.10$ & $0.50^{\mathrm{b}} \pm 0.10$ & $0.43^{b} \pm 0.02$ & $0.42^{b} \pm 0.01$ \\
\hline Syringic acid & $13.29^{\mathrm{a}} \pm 0.43$ & $12.78^{\mathrm{a}} \pm 0.12$ & $12.88^{\mathrm{a}} \pm 0.06$ & $12.90^{\mathrm{a}} \pm 0.03$ & $12.93^{\mathrm{a}} \pm 0.01$ \\
\hline Hydrobenzoic acid & $0.92^{\mathrm{a}} \pm 0.03$ & $0.93^{\mathrm{a}} \pm 0.02$ & $0.96^{\mathrm{a}} \pm 0.04$ & $0.97^{\mathrm{a}} \pm 0.03$ & $0.85^{\mathrm{a}} \pm 0.03$ \\
\hline \multicolumn{6}{|c|}{ Hydroxycinnamic acids } \\
\hline Caffeic acid & $0.79^{\mathrm{a}} \pm 0.11$ & $0.46^{\mathrm{ab}} \pm 0.09$ & $0.52^{\mathrm{ab}} \pm 0.13$ & $0.41^{b} \pm 0.02$ & $0.31^{\mathrm{b}} \pm 0.01$ \\
\hline$p$-coumaric acid & $0.71^{\mathrm{a}} \pm 0.01$ & $0.69^{\mathrm{a}} \pm 0.01$ & $0.68^{\mathrm{a}} \pm 0.01$ & $0.66^{\mathrm{a}} \pm 0.00$ & $0.56^{\mathrm{b}} \pm 0.02$ \\
\hline Ferulic acid & $0.27^{\mathrm{a}} \pm 0.07$ & $0.31^{\mathrm{a}} \pm 0.01$ & $0.30^{\mathrm{a}} \pm 0.01$ & $0.26^{\mathrm{a}} \pm 0.06$ & $0.22^{\mathrm{a}} \pm 0.00$ \\
\hline Caftaric acid & $55.28^{\mathrm{a}} \pm 1.52$ & $42.41^{b} \pm 1.84$ & $43.87^{b} \pm 2.64$ & $41.67^{b} \pm 0.08$ & $24.58^{\mathrm{c}} \pm 2.81$ \\
\hline
\end{tabular}




\section{Bentonite treatment}

\begin{tabular}{|c|c|c|c|c|c|}
\hline \multirow[b]{2}{*}{ Phenolic compounds } & \multirow[b]{2}{*}{ Control } & \multirow[b]{2}{*}{ PCT } & \multirow[b]{2}{*}{ BTL } & \multirow[b]{2}{*}{ PBN } & \multirow[b]{2}{*}{ SPM } \\
\hline & & & & & \\
\hline \multicolumn{6}{|l|}{ Flavonols } \\
\hline Rutin & ND & ND & ND & ND & ND \\
\hline Quercetin & ND & ND & ND & ND & ND \\
\hline \multicolumn{6}{|l|}{ Flavanols } \\
\hline Epicatechin gallate & $4.16^{\mathrm{a}} \pm 0.07$ & $3.92^{\mathrm{a}} \pm 0.05$ & $3.99^{\mathrm{a}} \pm 0.13$ & $3.90^{\mathrm{a}} \pm 0.05$ & $3.19^{b} \pm 0.14$ \\
\hline Gallocatechin & $23.07^{\mathrm{a}} \pm 1.04$ & $21.51^{\mathrm{a}} \pm 0.08$ & $21.71^{\mathrm{a}} \pm 0.52$ & $21.29^{a} \pm 0.35$ & $18.51^{b} \pm 0.44$ \\
\hline Epigallocatechin & $5.45^{\mathrm{a}} \pm 0.04$ & $5.03^{a} \pm 0.42$ & $4.39^{\mathrm{a}} \pm 0.44$ & $4.53^{\mathrm{a}} \pm 0.62$ & $5.40^{\mathrm{a}} \pm 0.23$ \\
\hline Catechin & $19.86^{\mathrm{a}} \pm 2.20$ & $14.58^{\mathrm{b}} \pm 0.73$ & $15.56^{\mathrm{ab}} \pm 0.91$ & $13.85^{\mathrm{b}} \pm 0.04$ & $13.72^{b} \pm 0.99$ \\
\hline Epicatechin & $9.26^{\mathrm{a}} \pm 1.55$ & $4.68^{b} \pm 0.64$ & $5.15^{\mathrm{b}} \pm 1.29$ & $4.10^{\mathrm{bc}} \pm 0.13$ & $0.74^{c} \pm 0.24$ \\
\hline Total phenolics* & $414.8^{a} \pm 7.1$ & $409.4^{\mathrm{ab}} \pm 2.0$ & $340.4^{\mathrm{c}} \pm 4.6$ & $398.9^{\mathrm{ab}} \pm 10.9$ & $394.3^{b} \pm 6.3$ \\
\hline
\end{tabular}

ND: not detected; different letters in the same row indicate a significant difference $(\mathrm{P}<0.05)$ according to one-way ANOVA and LSD test; *Concentration of total phenolics is expressed as gallic acid equivalent (mg GAE/L).

\section{CONCLUSIONS}

Bentonite fining is a common method used in wine industry to remove excess proteins in white wine before bottling. Addition of bentonite not only removes proteins but also phenolic compounds. This study investigated the impact of bentonite fining on phenolic composition in Chardonnay and Sauvignon Blanc wines. Bentonite fining significantly decreased the concentration of phenolic compounds in both wines due to the adsorption to bentonite or the interaction between proteins and phenolics. The decrease of individual phenolic compounds by bentonite fining varied depending on the type of bentonite with SPM (Ca-Na bentonite) in removing certain phenolic compounds associated with astringency, bitterness and hotness, which may consequently affect the mouthfeel and texture of resultant white wine. Thus, when selecting bentonite for protein stabilization, winemakers should also consider the negative impact on reduction of phenolic compounds by bentonite fining, in addition to the lees formation and the loss of aroma compounds.

\section{LITERATURE CITED}

Dordoni, R., Colangelo, D., Giribaldi, M., Giuffrida, M. G., De Faveri, D. M., \& Lambri, M., 2015. Effect of bentonite characteristics on wine proteins, polyphenols, and metals under conditions of different $\mathrm{pH}$. Am. J. Enol. Vitic., 66(4), 518-530.

Dordoni, R., Galasi, R., Colangelo, D., De Faveri, D. M., \& Lambri, M., 2015. Effects of fining with different bentonite labels and doses on colloidal stability and colour of a Valpolicella red wine. Int. J. Food Sci. Technol., 50(10), 2246-2254.

Dumitriu, G.-D., de Lerma Extremera, N. L., Cotea, V., \& Peinado, R., 2018. Antioxidant activity, phenolic compounds and colour of red wines treated with new fining agents. Vitis, 57(2), 61-68.

Ferreira, R. B., Picarra-Pereira, M. A., Monteiro, S., Loureiro, V. B., \& Teixeira, A. R., 2002. The wine proteins. Trends Food Sci. Technol., 12(7), 230-239.

Gawel, R., Schulkin, A., Day, M., Barker, A., \& Smith, P. A., 2016. Interactions between phenolics, alcohol and acidity in determining the mouthfeel and bitterness of white wine. Wine \& Vitic. J., 31(1), 30.
Gawel, R., Schulkin, A., Smith, P. A., \& Waters, E. J., 2014. Taste and textural characters of mixtures of caftaric acid and Grape Reaction Product in model wine. Aust. J. Grape Wine Res., 20(1), 25-30.

Gawel, R., Smith, P. A., Cicerale, S., \& Keast, R., 2017. The mouthfeel of white wine. Crit. Rev. Food Sci. Nutr., 1-18.

Gawel, R., Van Sluyter, S. C., Smith, P. A., \& Waters, E. J., 2013. Effect of $\mathrm{pH}$ and alcohol on perception of phenolic character in white wine. Am. J. Enol. Vitic., 64(4), 425-429.

Ghanem, C., Taillandier, P., Rizk, M., Rizk, Z., Nehme, N., Souchard, J.-P., \& El Rayess, Y., 2017. Analysis of the impact of fining agents types, oenological tannins and mannoproteins and their concentrations on the phenolic composition of red wine. LWT-Food Sci. Technol., 83, 101-109.

Goldberg, D. M., Karumanchiri, A., Soleas, G. J., \& Tsang, E., 1999. Concentrations of selected polyphenols in white commercial wines. Am. J. Enol. Vitic., 50(2), 185-193.

Gómez-Alonso, S., García-Romero, E., \& Hermosín-Gutiérrez, I., 2007. HPLC analysis of diverse grape and wine phenolics using direct injection and multidetection by DAD and fluorescence. J. Food Compos. Anal., 20(7), 618-626.

Gómez-Plaza, E., Gil-Muñoz, R., López-Roca, J., De La Hera-Orts, M., \& Martínez-Cultíllas, A., 2000. Effect of the addition of bentonite and polyvinylpolypyrrolidone on the colour and long-term stability of red wines. J. Wine Res., 11(3), 223-231.

Gougeon, R. D., Soulard, M., Miehé-Brendlé, J., Chézeau, J.-M., Le Dred, R., Jeandet, P., \& Marchal, R., 2003. Analysis of two bentonites of enological interest before and after commercial activation by solid Na2CO3. J. Agr. Food Chem., 51(14), 4096-4100.

Iland, P., Bruer, N., Edwards, G., Weeks, S., \& Wilkes, E., 2013. Chemical analysis of grapes and wine: techniques and concepts (2nd Edition ed.) Campbelltown, Australia: Patrick Iland Wine Promotions PTY Ltd.

Jiménez-Martínez, M. D., Bautista-Ortín, A. B., Gil-Muñoz, R., \& GómezPlaza, E., 2019. Comparison of fining red wines with purified grape pomace versus commercial fining agents: effect on wine chromatic characteristics and phenolic content. Int. J. Food Sci. Technol., 54(4), 1018-1026.

Lambri, M., Dordoni, R., Silva, A., \& De Faveri, D. M., 2010. Effect of bentonite fining on odor-active compounds in two different white wine styles. Am. J. Enol. Vitic., 61(2), 225-233.

Le Bourse, D., Conreux, A., Villaume, S., Lameiras, P., Nuzillard, J. M., \& Jeandet, P., 2011. Quantification of chitinase and thaumatin-like proteins in grape juices and wines. Anal. Bioanal. Chem., 401(5), 1541-1549. 
Main, G., \& Morris, J., 1994. Color of Seyval blanc juice and wine as affected by juice fining and bentonite fining during fermentation. Am. J. Enol. Vitic., 45(4), 417-422.

Majewski, P., Barbalet, A., \& Waters, E., 2011. \$1 billion hidden cost of bentonite fining. Austr. \& New Zealand Grapegrower \& Winemaker(June), 58-62.

Marangon, M., Van Sluyter, S. C., Haynes, P. A., \& Waters, E. J., 2009. Grape and wine proteins: their fractionation by hydrophobic interaction chromatography and identification by chromatographic and proteomic analysis. J. Agr. Food Chem., 57(10), 4415-4425.

Mesquita, P. R., Picarra-Pereira, M. A., Monteiro, S., Loureiro, V. B., Teixeira, A. R., \& Ferreira, R. B., 2001. Effect of wine composition on protein stability. Am. J. Enol. Vitic., 52(4), 324-330.

Muhlack, R. A., O’Neill, B. K., Waters, E. J., \& Colby, C. B., 2016. Optimal conditions for controlling haze-forming wine protein with bentonite treatment: investigation of matrix effects and interactions using a factorial design. Food Bioprocess Tech., 9(6), 936-943.

Ribéreau-Gayon, J., Peynaud, E., Ribéreau-Gayon, P., \& Sudraud, P., 1977. Sciences et Techniques du Vin. Vol. 4: Clarification et Stabilisation. Matériels et Installation. In. Paris: Dunod.

Salazar, F. N., López, F., Chiffelle, I., López, R., \& Peña-Neira, A., 2012. Evaluation of pathogenesis-related protein content and protein instability of seven white grape (Vitis vinifera L.) clones from Casablanca Valley, Chile. Eur. Food Res. Technol., 234, 509-515.
Singleton, V., Salgues, M., Zaya, J., \& Trousdale, E., 1985. Caftaric acid disappearance and conversion to products of enzymic oxidation in grape must and wine. Am. J. Enol. Vitic., 36(1), 50-56.

Stanković, S., Jović, S., \& Živković, J., 2004. Bentonite and gelatine impact on the young red wine coloured matter. Food Technol. Biotechnol., 42(3), $183-188$.

Tian, B., Harrison, R., Morton, J., Jaspers, M., Hodge, S., Grose, C., \& Trought, M., 2017. Extraction of pathogenesis-related proteins and phenolics in Sauvignon Blanc as affected by grape harvesting and processing conditions. Molecules, 22(7), 1164.

Van Sluyter, S. C., Marangon, M., Stranks, S. D., Neilson, K. A., Hayasaka, Y., Haynes, P. A., Waters, E. J., 2009. Two-step purification of pathogenesisrelated proteins from grape juice and crystallization of thaumatin-like proteins. J. Agr. Food Chem., 57(23), 11376-11382.

Vincenzi, S., Panighel, A., Gazzola, D., Flamini, R., \& Curioni, A., 2015. Study of combined effect of proteins and bentonite fining on the wine aroma loss. J. Agr. Food Chem., 63(8), 2314-2320.

Waterhouse, A. L., 2002. Determination of total phenolics. In Current Protocols in Food Analytical Chemistry, pp. I1.1.1-I1.1.8.

Waters, E. J., Alexander, G., Muhlack, R., Pocock, K. F., Colby, C., O’Neill, B. K., Jones, P., 2005. Preventing protein haze in bottled white wine. Aust. J. Grape. Wine Res., 11(2), 215-225. 